\title{
An Article of Agricultural Labour Problems in Barpeta of Assam
}

\author{
Makbul Hussain Khan, \\ Balikuri, Barpeta (Assam)
}

\begin{abstract}
Agricultural labours in Barpeta faces various problems. Agricultural labours means who works on the land of others on wages. Agricultural labours are not free from the bondage or slavery, their income living standard and social status are very low having unorganising system of farms workers. Objective: To know the social status of the agricultural labourers. To study the condition of their works. To know the magnitude of agricultural labours. Methodology of the study- the study includes only secondary methods of data collection and empirically study only. The paper includes problems of agricultural labours, government policy measures and suggestion for improvement of the agricultural labour conclusion- The study conclude that agricultural labourers condition is not good in Barpeta of Assam and government should take some proper steps to improve the conditions of agricultural labour.
\end{abstract}

\section{INTRODUCTION}

Agricultural labours in Barpeta of Assam is pertaining to $3 / 4$ of total labour force. Agricultural labour still remain serfdom or slavery system. Their income, living standard, social status is very low. Agricultural labour are those persons who work on the land of others on wages, for the major part of the year and can earn major portion of their income as a payment in the form of wages for works performed on the agricultural farms owned by others. They working both in the house and farms of their masters but faces various problems in Barpeta of Assam. The increase the number of agricultural labour has causes as increasing size of population, decline of cottage and village industries, evictions of small farmers, uneconomic holdings, growing indebtedness, deforestation, river erosion growth of capitalist farming etc are the main causes of agricultural labour problems of Barpeta of Assam.

\section{SCOPE OR IMPORTANCE}

The study on agricultural labour problem of Barpeta of Assam is very important. The total population of the district is 1693190 in 2011. Where 77 percent depend on agricultural activities. Growing population creates land problems, birth rate of the district increase 21.40 percent decade. Where 61 percent labour are landless agricultural labour, landless and marginal labour increasing due to river erosion and flood. Government employment policy has no better work in the district, labour of Barpeta are unorganized, bounded labour, no wage policy implemented in the district labour are low social status no any bargaining power, land are concentration few farmers only, most holding in less than one hectares so agricultural labour problems arises in the district disguised seasonal employment increasing day by day. More over their illiteracy poverty lack of training facilities - increasing the problems.

\section{OBJECTIVE OF THE STUDY}

The study have following are the objectives (a) - To know the social status of the agricultural labour of the Barpetadistrict (b)To study the condition of their works. (c)To know the magnitude of agricultural labours of Barpeta district.

\section{METHODOLOGY}

The study of agricultural labour problem of Barpeta district based on secondary method of data collection from various books, News papers ect.

\section{POSITION OF AGRICULTURAL LABOUR}

Agricultural labours is provided mostly by economically and socially backward section; poor section for the tribes also swell their ranks. It may be divided into four categories-

(a) Landless labourers who are personally independent but who work exclusively for others.

(b) Petty farmers with tiny bits of land who devote most of their time working for others.

(c) Farmers who have economic holding but who have one or more of their sons and dependants workings for others prosperous farmers.

(d) Land less labours who are attached to the landlords

The last group of agricultural workers has been more or less in the of salves; they are known as bonded labour. They do not normally receive wages in case but are generally paid in kind. They have to work for their principals or masters as contractual basis earn can't shift from one or another with due time. Above mention the 
other groups of labour first second and third are also important but the problems of land less labours is the most serious problems in the rural areas.

\section{MAGNITUDE OF AGRICULTURAL LABOUR}

Accurate datas about the number income, standard of living etc of rural labour are not available yet some information is available in the form of the reports of committees and commissions. More over, the percentage of land less labourers as a proportion of rural labour force has increased from 16 percent in 1991 to 29 percent in 2001. Official data further shows that about 61 percent of the rural households either have no land or hold uneconomic holding of less than 1 hectare. These 61 percent of households in Barpeta of Assam. Total farming family of the District is 181805 and total agricultural area is 330,000 hectare. 60 percent agricultural labour has less than 1 hectare holdings. The increase in the number of agricultural labour has resulted from increase in the size of population decline of cottage and village industries eviction of small farmers, uneconomic holding growing indebtedness and growth of capitalist farming.

\section{CAUSES OF THE POOR ECONOMIC CONDITION OF FARM LABOUR}

[1] Unorganised - Agricultural labourers in Barpeta of Assam are totally unrecognised as they are ignorant illiterate and widely scattered. Thus the farm workers have no capacity to bargain for securing a fair wage level.

[2] Low social status - Farm workers mostly belong to depressed classes and thus they are lacking the courage to assert there basic rights.

[3] Seasonal unemployment - As the agricultural operations are seasonal thus the farm worker are often facing the problem of seasonal unemployment and under-employment. Farm workers on average get about 200 days in a year.

[4] Absence of alternative occupation:- In the rural areas the farm workers are not getting alternative job when they suffer seasonal unemployment.

[5] Growing indebtedness - Agricultural labporers in Barpeta of Assam are highly indebted. As the lend of wages are very poor thus the farm workers have been borrowing from land lords and become bonded labourers ultimately it can be said that the agricultural labourers in Barpeta of Assam are living in inhuman conditions and in the absence of organised status. They are deprived of all the basic amenities of their life.

[6] Natural Factors:- In Barpeta district of Assam chronically affected by flood and river erosion. Nearly 31000 hectares agricultural land affected by flood and erosion every years and huge loss of the farmer.

\section{GOVERNMENT POLICY OR MEASURES ADAPTED TO IMPROVE THE CONDITIONS OF FARM WORKERS}

[1] abolition of bonded labour: - The Indian constitution declared the practice of serf demand offence. It has also abolished agrarian slavery including forced labour by law but it will take sometime before it is removed in practice.

[2] The minimum wage act passed in 1948 by state government were advised to fix minimum wages for labour within three years. The minimum wages are fixed keeping in view the total costs and standard of living. But due to some practical difficulties most of the state could not fix the minimum wages till 1974.

[3] Other legislative measures: After passing legislation for fixing ceiling on land were acquired surplus lands and distributed it among the land less labourers. About 74 lakh areas of land were acquired as surplus lands and distributed it among land less labour.

[4] In India various state have passed necessary legislation for providing housing sites to agricultural labourers. Again under minimum needs programme and 20 point porogramme high priority is being attached to rural housing site cum-house construction scheme.

[5] Employment Guarantee Scheme: For providing alternative source of employment among the agricultural labourers various scheme have already been launched by both the central \& the state governments. These scheme (FGS) by the Govt. of Maharashtra. Food for Work Programme (FWP), National Rural Employment Programme (NREP), Rural Landless Employment Guarantee Programme (RLEGP) Jawahar Rozgar Yojana (JRY) etc. Among all these schemes NREP and RLEGP got importance.

[6] VI.Other Special Agencies :- During the fourth plan two special agencies-small farmers development Agency (SFDA) and Marginal Farmers and Agriculture labourers development Agency (MFAL) were developed for conducting various works like irrigation land conservation dairy development piggory 
development poultry, breeding etc. During the fifth plan both agencies were merged into a single programme.

[7] 20 point programme the government introduced the 20 point economics programme in July 1957 in which steps were taken to improve the economic conditions of landless workers and other weaker sections of the society in rural areas. These steps include speedy implementation of ceiling laws and then distribute the surplus land among the landless labour. Making provision for housing sites for landless labourers, abolition of bonded labour liquidation of rural indebtedness and moratorium on recovery of loans from landless workers and receiving og the minimum wage legislation etc. Some other special agencies like SFDA, MFAL etc.

\section{FINDING}

Finding is that the district increasing agricultural labour problem due to high birth rate and decreasing agricultural land, on account of river erosion and sends cover of char areas. Increasing landless labour and uneconomic holding in the district. The district has no implemented wage policy at all. Government policy does not works better in the area. The land concentrated few big farmers and landless agricultural labour are unorganized, bounded and low social status and having their indebtness, illiteracy poverty absence of alternative occupation and seasonal unemployment are found in the district of Barpeta. So there creates agricultural labour problems in the Barpeta district.

\section{SUGGESTIONS FOR IMPROVING THE CONDITIONS OF AGRICULTURAL}

\section{LABOURERS}

[1] Implementation of minimum wage act :- To implement the minimum wage act seriously and to revise the minimum wages periodically considering the changing price level of the country.

[2] Bargaining Power :- To improve their bargaining power the agricultural workers should be organised through the formation of farm unions of labourers under the protection and support of the government.

[3] Abolition of Bonded Labour :- To abolish serfdom among the landless agricultural labourers totally.

[4] Distribution of Surplus Land :- To rehabilitate the agricultural labourers on the acquired land declared surplus under ceiling laws and also on the new reclaimed land.

[5] Alternative Sources of employment: to create alternative sources of employment by developing small scale and cottage industries in rural areas.

[6] Social Security Measures: To introduce social security measures for the agricultural labours and also to introduce compulsory insurance on marginal contribution and also to institute old age pension scheme for the agricultural workers by the government.

[7] Fixing working hours: to improve the working conditions of agricultural labour by enforcing fixed hours of work banning child labour etc.

[8] Modern Method :- To improve the working conditions of agriculture by adopting improve intensive methods and multiple cropping for raising the productivity of agricultural labourers and promote co-operative farming in rural areas.

[9] Flood and River Erosion Control :- Adequate measures must be taken to overcome the problems of agriculture in Assam created by natural factors. Extensive flood control measures should be adopted to prevent huge loss and devastation created by ever recurring flood in Assam. In Assam river Erosion must be control to save the agricultural land and labourers.

[10] Economic Measures:- To make agriculture move remunerative active economic measures must be introduced. Subsidiary agrobased industries must set up in rural areas. So that surplus labour in agriculture sector can be utilised in these industries. Proper steps must be taken to break the vicious circle of poverty.

[11] Human Development :- For the improvement of agricultural productivity in the state the quality of farmer must be improved through education, both general and technical. To save the agricultural labour from epidemics and other diseases, adequate public health measures must be undertaken.

\section{CONCLUSION}

In the conclusion we can conclude that the condition of agricultural workers is not so good in Barpeta of Assam, their living standard and income is very low. For the improve the conditions government should take proper steps for various aspect for agricultural labours, like wage reforms, new methods for agriculture, hours of works, improve the living conditions and over coming the natural factors like flood and erosion etc.

\section{REFERENCE}

[1.] K.p.m sundharam- indian economics thirty seventh edition 1997 new delhi

[2.] Dhar p.k-indian economy, kalyani publishers, $17^{\text {th }}$ edition 2009

[3.] Dhar p.k-assam economy, kalyani publishers, eiahth edition 2007

[4.] Dr b.p taygi agricultural and rural develoment economics.

[5.] Guptas r. Popular master guide romesh publishing house 2009.

[6.] Newspapers - Pratidin. Khabar etc. 